\title{
ПРОПИСНАЯ БУКВА КАК СРЕДСТВО ВЫРАЖЕНИЯ ДУХОВНОСТИ: ИСТОРИЯ И СОВРЕМЕННОСТЬ
}

\author{
М.А. Петриченко
}

На протяжении всего развития русского языка в тех случаях, когда возникал конфликт смысла и грамматики, побеждал смысл.

$$
\text { В. Одинцов }
$$

Орфография в своем идеале кодифицирует написание всех без исключения языковых фактов, а ее правила для пишущих являются строго обязательными. В то же время важно отметить, что орфография, графика, пунктуация в их неразрывной связи с содержанием текста задерживают на себе внимание не только филологов, но и философов. Среди последних работ в этой области выделяется опубликованная в 2003 году в «Вопросах философии» статья Вадима Россмана «Техники пунктуации: знак препинания как философский метод». Основной вывод философа - «мы находим множество прямых деклараций относительно знаков препинания как метода и их использования в концептуальных целях, вплоть до провозглашения их символами целых социальных и философских направлений... В области философии при этом значение знаков препинания выходит за пределы чисто экспрессивной функции» [17, с. 69].

В нашей статье анализируется нормативно-орфографический аспект прописной буквы (ПБ) как составная часть многогранной проблемы духовности. Возможность такого подхода обусловлена тем, что выбор прописная-строчная, отражая лингвистическую эрудицию пишущего, одновременно представляет его отношение к вере, добру, злу, красоте, творчеству, являя тем самым ПБ своеобразным орфографическим средством выражения духовности и способом познания действительности.

Актуальні проблеми духовності

(Відп. ред.: Я.В. Шрамко)

Кривий Ріг (2005), 258-264 
Как же появилась в звуко-буквенных системах письма ПБ, получившая в русском языке-в сопоставлении с «обычной», строчной буквойспецифические «духовные» функции? Уже в античные времена в средиземноморской письменной традиции наличествовало несколько почерков, или типов письма. Наиболее распространенными были два. На керамике, каменных плитах, стенах домов острым каламом выбивались, выцарапывались большие тяжелые квадратные буквы, сливавшиеся в сплошную строку (без пробелов и знаков препинания) монументального почерка. (Этот почерк стилизуют, к примеру, надписи на стелах Марсова поля в Санкт-Петербурге). На папирусе, пергаменте, шелке, а затем и бумаге кисточкой, тростниковым пером мелко выводилось более округлое скорописное курсивное писъмо. Так как «тела знаков тесно связаны с функциями, которые они могут выполнять», то «для графики знаков в принципе существует возможность использовать их зрительные и пространственные характеристики» [7, с. 21].

Начиная с Византийского периода развития греческого письма (IVVвв.) крупные буквы монументального почерка писцы постепенно используют как своеобразную подсказку, ориентир, указывающий на начало текста, фрагмента, фразы. Грамматисты, уже распределявшие к тому времени слова по частям речи, стали с ПБ писать имена, тем самым выделяя их среди других категорий слов. Окончательное оформление греческого дубль-алфавита, т.е. алфавита из прописных и рядом стоящих строчных букв, произошло в XIV-XVвв. Прописная буква в это время осознавалась как большая, заглавная, инициальная, монументальная, начальная, - а следовательно, и значительная, торжественная [5, с. 12].

В первых памятниках славянской письменности (IX-XIвв.) не было деления букв на строчные и прописные. Каждая буква имела одну форму, близкую к современной строчной или прописной. В начале книги, текста, иногда листа, абзаца, строки даже не писались, а рисовались киноварью буквы, отличающиеся большими по сравнению с остальными буквами размерами. Различение графики строчньх и больших букв совпадает во времени с введением пробелов между словами (XV-XVII вв.), а дубльалфавит появляется в русских букварях уже в XVII века. Одновременно с расподоблением графики прописных и строчных букв нормировалась передаваемая от одного писца к другому практика употребления прописной буквы, опирающаяся на традицию западноевропейских языков - латинского, немецкого, греческого и др., где ПБ употреблялась очень широко.

Так как первые славянские книги представляли собой переводы греческих богослужебных и канонических текстов, остановимся на эволюции традиции написания ПБ в религиозной лексике. В богослужебных книгах писались с ПБ имена «Трех лиц Божества и высших существ, составляющих предмет религиозного почитания христиан: Бог, Господъ, Тво- 
рец, Всевышний, Спаситель, Богородица, Свлтой Дух, Святая Троица и др.; названия религиозных праздников, постов; слова Псалтырь, Библия, Евангелие, Новый Завет, Ветхий Завет. Прописная буква употреблялась в написании слов Царь, Император, Самодержеи, Святейший Cuнод и т.п., а также в местоимениях, указывающих на небесных и земных правителей: $O \mu, E_{\mathcal{M}}, E_{2 о}$ и др.» [2]. Такая орфография сразу же перешла из церковных, духовных текстов в светскую литературу. ПБ делала стиль изложения высоким, подчеркивала «святость» религиозных слов, их значимость, торжественность. Церковная и царская цензура не допускали к печати и продаже книги, в которых с малой буквы писались слова, называющие Бога. Например, Ученый комитет запретил распространение книги протопресвитера В.Баженова «О вере и жизни христианской», в которой наборщики случайно местоимения Который, Свой, Сам, Он, когда они относились к имени Господа Бога, везде начинали со строчной буквы, а не с большой. Равным образом существительные Дева (Святая Дева Мария), Тело и Кровъ (Христовъ) - писались в этой книге с малой буквы. Книгу постановили перепечатать.

С другой стороны, цензоры очень строго следили и за тем, чтобы ПБ не употреблялись в словах, обозначающих обыденные имена и явления. Даже традиционный в западноевропейской литературе прием написания с ПБ героев-животных басен вызывал запреты русской цензуры. Из-за них, например, были изъяты из публичных библиотек книга «Басни Эзопа в русском переводе» (М., 1880 г.) и хрестоматия для детей «Золотая книжечка» (М., 1890 г.) со сказкой А.С.Пушкина «О войне Мышей и Лягушек», в которой рассказывается о Царе Львов, о Короле Мышей и Лягушек - как об Их Высочествах. Функция прописной буквы как стилистического средства художественной речи и в более позднее время не учитывалась строгой цензурой. Так, для того чтобы напечатать «Стихи о Прекрасной Даме» А. Блока, в которых о земной женщине писалось Пречисто Вечная Жена, Тихая, Она, Ть, Закатная Таинственная Дева и др., друзья Блока отправили в цензуру экземпляр, в котором ПБ вообще не употреблялась. После цензурного просмотра вносить в текст какие-либо изменения запрещалось, но т.к. в цензурных правилах ничего не говорилось об изменении графики букв, в одобренном цензурой экземпляре друзья А.Блока заменили строчные буквы прописными [1]. Таким образом, прописная буква в определенной части религиозной лексики непосредственно манифестировала веру в Бога.

«Бога нет - и все дозволено»- для такой идеологии оказалось необходимым заменить в словах веры ПБ, утверждавшие ее, на обычные, и тем самым отрицающие ее, строчные. Сейчас уже невозможно определить, кто был пионером такой рокировки букв, но совершенно ясно, что она стала ключевой, знаковой для атеизма. Размышляя в своем «Днев- 
нике писателя» о полете идей, Ф.М. Достоевский записал: «Идеи летают в воздухе, но непременно по законам, слишком трудно для нас уловимым... Через два-три десятка лет мысль уже охватывает все и всех, 一 и выходит, что торжествуют не миллионы людей и не материальные силы, по-видимому, столь страшные и незыблемые, не деньги, не могущество, а незаметная вначале мысль» [3, с.47].

Новые правила правописания, разработанные Народным комиссариатом просвещения и известные в качестве реформы графики и орфографии 1917-1918 гг., декларировали, что при проведении реформы не допускается принудительное переучивание тех, кто уже усвоил правила прежнего правописания, и что для всех остаются в силе лишь те правила, которые являются общими для прежнего и нового правописания, и ошибками считаются лишь нарушения этих правил. Данная реформа не предлагала новых правил употребления ПБ. Однако давление атеистической идеологии было настолько мощным, безапелляционным, что без всякого указания (для русского интеллигента таковым часто служил пугливый здравый смысл) ранее писавшаяся с ПБ религиозная лексика во всех стилях русского литературного языка стала писаться со строчной: бог, господъ, библия, богородица, мессия, пасха и др. Правила русской орфографии и пунктуации 1956 года закрепили эту практику написания следующим Примечанием к п. 103: «Названия религиозных праздников и постов, а также дней недели, месяцев и т.д. пишутся со строчной буквы, например: рождество, троицын день, святки, масленица, великий пост, курбан-байрам, четверг, сентябръ». Напрасный труд искать правила о написании слов Бог, Богоматеръ, Богородица, Господъ, Библия и др. в этом научном документе, из которого исходили при составлении учебников, разнообразных словарей, справочников, энциклопедий.

Тем не менее в советских словарях различных типов - орфоэпических, орфографических, толковых - наглядно проявлялась установка писать слова бог, богоматерь, богородица, мессия, господь со строчной буквыкак имена нарицательные. Эта установка была основной в изучении орфографии в школе, определяла через многочисленную атеистическую воспитательную работу модус поведения ребенка и юноши, его оценки и взгляды на мир и окружающих. Со строчной писались также все местоимения, заменяющие существительные Бог, Богоматерь и др., что часто затемняло содержание текста. Интересный пример приводит текстолог С.А.Рейсер: «Порой орфография, неправомерно модернизируя, делает текст непонятным. По старой орфографии «Он» в значении «бог» (обратите внимание на строчную! - М.П.) писалось, конечно, с прописной буквы. По современному правописанию это правило отменено. В двадцать второй главе пятой части «Анны Карениной» графиня Лидия Ивановна, утешая Каренина, говорит ему: «Пора наша есть любовь, та любовь, ко- 
торую он завещал нам». «Он» в советских изданиях печатается со строчной буквы, чем создается двусмысленность: из контекста неясно, что речь идет о боге» [15, с. 185].

Такого рода модернизация распространялась и на переводную литературу. Например, в русском издании (1987 года!) сборника статей выдающегося английского философа Бертрана Рассела «Почему я не христианин» [14] слово бог везде пишется со строчной буквы, хотя в оригинале Рассел, несмотря на свое более чем критичное отношение к христианской религии, в полном соответствии с правилами английской орфографии, использовал ПБ.

Все же, не смотря на идеологию официального атеизма, в записях «для себя» многие продолжали писать слово Бог с ПБ. Примечательно, что переживший полуголодную эвакуацию, Отечественную войну с морем ее крови, человеческого предательства, низости, падения, но и победы, теплом нерушимого фронтового братства, замечательный советский философ Эвальд Ильенков определяет в своем фронтовом блокноте: «Современный человек, как человек, нехорош тем, что внутри себя не имеет того внутреннего устремления, скрашенного радужным цветом поэзии, которое раньше называли Богом. . . Слишком материалистическое восприятие всего... У меня все растет и крепнет убеждение, что нам очень и очень необходим Бог» [4, с. 10]. По мысли Э. Ильенкова, вера в Бога, чтение Библии (в письме к студенту А. Суворову он напишет - «Не удивляйся, что я тебе цитирую Библию, - это ведь вовсе не поповская книга» [4, с.447]) поднимают человека от земли, открывают его сознание материально не осязаемому миру.

Орфографист Л.П. Калакуцкая заметила, что «семидесятилетнему периоду атеистического сознания вполне соответствовала и грамматическая характеристика восклицаний господи! и боже! как междометий» [6, с.65], что давало основание писать их с малой буквы. Старые русские интеллигенты за этими словами статуса междометий не признавали - «Ну, да Бог с ним!»; «Я, ей-Богу, больше не буду никогда и никому давать разрешения» и др. [11].

Религиозная лексика в работах лингвистов того периода определялась взятым в ироничные кавычки термином «священный»- «священные слова». Владимир Максимов, сделавший темой своих многочисленных романов («Прощание из ниоткуда», «Ковчег для незваных», «Семь дней творения» и др.) противопоставление «стяжения Духа Святого» воинствующему атеизму, который, по его мнению, есть мировое зло, на слова «Бог обман» устами одного из героев (Л. Гупака) отвечает: «Любая вера - добро. „Тьмы горьких истин нам дороже нас возвышающий обман“... На века сказано. Думали свет открыли: Бога нет! Но светом этим высвободили в смертном его звериную суть, инстинкты животные... Вместо мечты 
о вечной жизни подкинули обещание всемирного обжорства и ничегонеделания. А он - человек-то, как наелся, так сызнова его к вечной жизни потянуло» [10, с.80]. Верность данного наблюдения подтверждается, в частности, тем орфографическим фактом, что с 1985 года религиозная лексика, которая всегда писалась с ПБ в теистической литературе, начинает писаться - вопреки существовавшим орфографическим правилам! с ПБ и в светских текстах. Такое написание отразило переживаемое обществом возвращение исторической памяти и новую идеологию.

В учебной и справочной литературе последних лет, например в орфографическом словаре «Как правильно? С большой буквы или с маленькой?», написание связанных с религией слов регламентируется в специальном разделе [9, с. 22-24]. Правила этого раздела основываются на уже цитированном нами «Русском правописании» Я.К. Грота и отражают стихийно сложившуюся практику современной массовой печати. В отличие от аналогичных справочников эпохи воинствующего атеизма [16] в новом справочнике правила написания (отметим, что он не регламентирует, а рекомендует) ПБ в словах, связанных с религией, многочисленны. Они указывают на написание с ПБ: 1. Слова Бог и имен Бога в разных религиях (Саваоф, Аллах, Шива и др.); 2. Слова Богородица, Троица, Дух Святой и др. синонимов к слову Бог (Господь, Всевышний и др.) и Богородица (Царица Небесная и др.) (Однако примечание 1 этого справочника, как нам кажется, неправомерно сужает сферу написания с ПБ местоимений, заменяющих слова Бог, Богородица и др. На наш взгляд, эти местоимения также относятся к вечным духовным ценностям человека и во всех стилях должны писаться с ПБ. Лишним представляется и примечание 2-о междометном статусе восклицаний слава богу, ейбогу, боже мой: вопреки примечанию их следует, как представляется, писать с ПБ). 3. Названий категориальных для религии понятий (Kpecm Господень, Страшный суд и др.), праздников (Рамадан, Шаббат, Пасха); 4. Названия культовьх книг (Библия, Коран, Веды и др.) В словаре также указано, как должно писать названия конфессий, высших органов церковной власти, церковных должностных лиц, церковных служб и др. ${ }^{1}$

Заключая, отметим, что написание ПБ в лексике, относящейся к религии, оказалось наиболее зависимым от идеологии. В разных идеологических условиях религиозная лексика рассматривалась нормализаторами либо как наполненная высоким лексико-стилистическим содержанием ПБ, либо как «опиум народа» - строчная буква. Орфографическая заме-

\footnotetext{
${ }^{1}$ Рекомендации о написании слов высокой духовной лексики с ПБ отражаются и в написании слов черт, дъявол, бес и т.п. Как имена нарицательные, данные слова пишутся со строчной. Однако в текстах современной литературы, в средствах массовой информации отчетливо намечается тенденция писать подобные нарицательные с ПБ. Почему?
} 
на строчной буквы прописной в этих словах означает не простую реанимацию прежней орфографии, но символизирует возвращение исторической памяти и - безусловно - подъем духовной жизни общества.

\section{1 Литература}

[1] Блюм A.B. Орфография и царская цензура // Русская речь.1978. - №1. - C. 110-115.

[2] Грот Я.К. Спорные вопросы русского правописания от Петра Великого доныне. // Изд. 2. - СПб., 1876, ч. 2.

[3] Достоевский Ф.М. Полн. собр. соч. В 30 т. - Т. 24. - Л., 1973.

[4] Илъенков Э.В. Философия и культура.-М., 1991.

[5] Истрин В.А. Возникновение и развитие письма. - М., 1965.

[6] Калакуцкая Л.П. Имена собственные в орфографическом и других лингвистических словарях //Вопросы языкознания. - 1997. - №3. C. 7-15.

[7] Кубрякова E.C. Возвращаясь к определению знака // Вопросы языкознания, 1993. - №1. - С. 18-29.

[8] Литературная учеба. - 2004. - №5. - С.4-15.

[9] Лопатин В.В., Нечаева И.В., Чельцова Л.К. Как правильно? С большой буквы или с маленькой?: Орфографический словарь.-М., 2002.

[10] Максимов B.E. Собр. соч. в 9-ти т. - Т. 4.-M., 1993.

[11] Переписка М. Горького: В 2-х т.- Т. 1.-M., 1986.

[12] Петриченко М.А. Очерки по пунктуации: Учебное пособие.-Кривой Рог, 2003.

[13] Правила русской орфографии и пунктуации. - М., 1956. - С. 70-114.

[14] Рассел Б. Почему я не христианин: Избр. атеист. произведения. - М., 1987.

[15] Рейсер C.A. Палеография и текстология.-М., 1970.

[16] Розенталь Д.Э. Прописная или строчная? (Опыт словаря-справочника). - М., 1984.

[17] Россман Вадим. Техники пунктуации: знак препинания как философский метод // Вопросы философии. - 2003. - №4. - С. 68-76. 